UDC 378.016:811.11

DOI: $10.17223 / 24109266 / 10 / 5$

\title{
TRANSLATION OF COMPLICATED LINGUISTIC CATEGORIES WITHIN THE CREATION OF SUBTITLES IN CHINESE
}

\author{
T.V. Privoritskaya, A.S. Kosmacheva
}

\begin{abstract}
This article deals with basic features of subtitles creation, introduces us the concepts of "translation with subtitles" and "subtitling". Translation with subtitles is shown as an independent type of translation, creation of subtitles requires special attention to the process of writing the text of translation in strictly limited number of symbols. Special attention is given to translation of complicated linguistic categories (idioms, language relias, loanwords, etc.) within the creation of subtitles. The analysis of dialogues in the Chinese series “家有儿女” ("House with kids)" highlights the basic transformations in translation with subtitles from Chinese into Russian.
\end{abstract}

Keywords: subtitles; audiovisual translation; subtitling; translation; complicated linguistic categories.

\section{Introduction}

Over the last years audiovisual translation plays an important role in translation practice. Today, it's very difficult to imagine the entertainment industry without foreign movies. This situation leads to the need of highquality and dynamically equivalent translations for the Russian audience.

One of the most frequent types of audiovisual translation which applies to all the Chinese movies is subtitling.

Subtitling is defined as a presentation of dialogue translation in a film in the form of titles usually at the bottom of image or shot on the screen. Subtitles usually appear and disappear in correspondence to original dialogue part and always are added to the image on the screen.

\section{Peculiarities of subtitles creation process}

Subtitling is a brief retelling of film dialogues which is presented as a text at the bottom of the frame. Without going into details, the difference between translation with subtitles and dubbing is that the first one is a translation of an oral text, and the second one is an interpreting of this text. Since the text is not pronounced and reproduced only in writing, this additional conditionality changed translation mission and requirements [2: 141]. One of the main point is that there is no need to focus on the lip movements of the actors and the approximate length of a word in translation with subtitles.

From the technical point of view, written and oral presentation of verbal cinematic information contradict with each other in translation with sub- 
titles, as translation with subtitles isn't full and complete translation, and provides only semantic equivalence and compressed information. In this regard, the concept of "translation with subtitles" is sometimes brought into question.

In general, the mission of translation is to make the massage understandable to the recipient, therefore translation with subtitles cannot be considered as a independent type of translation. Translation with subtitles reserves the original sound track (voice, intonation, rhythm), but it occupies parts of the video. It follows from here one of the major technical constraints - in order not to make watching into reading it's necessary to minimise the number of rows and symbols in subtitle [2: 142].

\section{Translation transformations of complicated linguistic categories within subtitling}

Complicated linguistic categories include realias, proper nouns, idioms (idiomatic expressions), phraseological unities (fixed phrases, proverbs, sayings), Chinese special idioms called "chengyu", loanwords, wordplays. This group of categories brings the problem of creating a dyamically equivalent translation of audiovisual texts and subtitles in particular. The ability to translate correctly some things referred to the original text and images associated with them demands knowledge of the reality which is shown in the translated work.

The Chinese series called “家有儿女” (“House with kids”) was chosen as a research filed for this work. It's a comedian sketch about an ordinary Chinese family.

In the series there are following Chinese national-specific realities:

1) 有的吃菜, 有的吃馄饨 - "Somebody wants vegetables, somebody wants dumplings"

“馄饨”, in translation “wontons", - traditional Chinese food, which is somelike Russian dumplings. That's why, "wontons" is changed to "dumplings" by using functional replacement.

2) 让孩子们吃一顿忆苦饭 - "Feed children with food of tough time"

“忆苦饭”, in translation “food of tough time” (lit. "food which reminds you about past tough and hungry time"), - it is a figurative name of tough time' food, when people didn't have enough money for normal food they ate all that could save them from starvation. Russia also had those terrible years, so the translation is the same as in Chinese. However, literal translation was applied to the reception of compression.

3) 这B写得跟糖葫芦似的 - “The letter 'B' similar to a caterpillar”.

“糖葫芦”, in translation "sugar-coated berry", - one of the traditional Chinese sweet. This sweet is really like the writing of the letter "B". Howev- 
er, literal translation can cause misunderstandings among the Russians audience, that's why the adaptation method is appropriate here.

In the series there are following wordplays:

1) 买书去 - 买蔬菜 these expressions are similar in sound but their meanings are completely different.

买书去 - "buy books"

买蔬菜 - "buy vegetables"

This wordplay is clear only when you watch the whole episode of the series. The meaning of the wordplay is that replacement of two similar in sound words can affect the whole situation.

In order to keep to the wordplay in translation into Russian it's possible to leave the original translation and translate as follows:

买书去 - "buy books"

买疏菜 - "buy goods"

2) 野草 - 野菜 these two words are similar in sound and their meaning.

严格地说就是一种野草 - “Roughly speaking. it's grass”

我刚才有口误啊, 是一种野菜 - “Oh, sorry, it's green”

野草 and 野菜 in translation “weed" and "wild edible plant" respectively. In translation into Russian the adaptation method was used. As a result, the word "grass" means something non-edible, and "green" means something that people eat.

The speaker in the episode explained that it was a slip of the tongue, but that slip made the 草 and 菜 wordplay.

3）我昨天叫您的是 nothing, 不是闹醒 - “Yesterday I taught you the word 'nothing', and not 'how sing'"

In this subtitle there is following wordplay: "nothing" and “闹醒” "cause to wake up".

This subtitle is rather difficult to translate into Russian because in addition to Chinese, there appears one English word. In order to translate this sentence correctly the adaptation method was used: the words "nothing” and “闹醒” were replaced by other lexical items, which similar in sound in Russian.

In the series there are following loanwords: mins?"

1) 您这野菜里头有那 $\mathbf{A B C D}$ 吗? - “Does the green have any vita-

In this expression the speaker used the abbreviation $A B C D$ which means the most essential vitamins for the body. The generalisation method was used in translation into Russian.

Also, the compression method was used in order to reduce the number of characters per line in subtitle. 
2) 英语是得从最基础的 $\mathbf{A B C}$ 开始学习 - “We'd begin to study English from the Alphabet"

This loanword reflects the connection with the English language and gives the expression of emotion. The translated "alphabet" doesn't distort the "ABC" meaning.

In the series there are following phraseological unities:

1) 一百五十元完璧归赵 - “Here my precious 150 yuan”.

The “chengyu” 完璧归赵 is translated as “return the jade to its state of Zhao", but this literate translation isn't appropriate here. That's why the functional analogue was used, in which there was a figurative meaning.

2) 我只好挑灯夜战了 - “I have to work into the night".

The "chengyu" 挑灯夜战 is translated as "to raise a lantern and fight at night". The explication method was used there, because literal translation was absolutely inappropriate.

3) 你别拉我下水啊 - “Don't drug me into this”.

Is translated as "to drug into the mire", but it also has the figurative meaning "to drug somebody into bad deal". Here is used the functional analogue without figurative meaning.

In the series there are following idiomatic expressions:

1) 林子大不了什么鸟都有 - “The world is full of surprises"

This expression can be literally translated as "there are a lot of birds in the forest", but according to the episode this translation isn't appropriate. That's why the idiomatic expression was translated using the functional analogue.

2) 别瞎忙着给我拍马屁 - “Stop toadying!”

In this subtitle we can see the idiomatic expression 给...拍马屁, which can be literally translated as "clap the horse on the rump". But it also has it's figurative meaning - "to toady", "to flatter".

In the series there is also a category of words like slang, jargonisms and colloquial words.

1) 我要是把您教不好, 我也没什么好下场 - “If I don't teach you well, I'm not going to have a good end"

This example shows us the jargonism 下场 which can be translated as "end, fate, mess".

2) 跟你说的一样, 说我神经病 - “Just like you said - I'm crazy".

Firs of all, the word 神经病 is a medical term and translated as "neuropathy" (mental disease). The jargonism takes the meaning from the literal translation and sounds like "sicko, rugger-bugger, crazy". The figurative meaning of this word is an excellent variant of translation here.

A group of proper nouns is a special group of complicated linguistic categories. 
1) 刘星 - “Liu Xing”

2) 小雪 - "Xiao Xue"

3) 方老师 - “teacher Fang”

4) 魏征叔叔 - “uncle Wei Zheng”

It goes without saying, that all the proper nouns in Chinese are translated with transcription according to the certain rules.

As for the third and forth example is concerned, we can see not only people's names, but also their social status and attribute. This fact should be taken into consideration in translating process, because such kind of additional information can be the main idea in the context and we can omit the name.

\section{Conclusions}

To sum up, the complicated linguistic categories are quite common in the Chinese language. Each category requires special attention and adequate translation. It's absolutely impossible to apply the same translation transformations to their general group. Therefore, translators have to be serious and attentive to audiovisual translation of realias, phraseological unities, idiomatic expressions, loanwords, etc. so that the audience can receive translated information without losing its original meaning.

\section{References}

1. Kozulyaev, A.V.: Obucheniye dinamicheski ekvivalentnomu perevodu audiovizual'nykh diskursov: innovatsionniye podkhody shkoly audiovizual'nogo perevoda [Teaching the dynamically equivalent translation of audiovisual discourses: innovative approaches of the school of audiovisual translation] // The Bulletin of Perm National Research Polytechnic University. 13. pp. 3-24. (2015). (In Russian)

2. Gorshkova, V.E.: Osobennosti perevoda fil'mov s subtitrami [The features of translation of films with subtitles] // The Bulletin of Reshetnev Siberian State Aerospace University. 3. pp. 141-144. (2006). (In Russian)

3. Fedorov, A.V.: Osnovy obshchey teorii perevoda (lingvisticheskiye problemy) [Fundamentals of the general theory of translation (linguistic problems)]. Textbook for foreign language institutions and faculties, $5^{\text {th }} \mathrm{Ed}$. Moscow: OOO Izdatel'skiy Dom FILOLOGIYA TRI (2002). (In Russian)

4. Schichko, V.F.: Kitayskiy yazyk. Teoriya i praktika perevoda [The Chinese language. Theory and practice of translation] Moskva : Vostok-Zapad. (2004). (In Russian)

\section{Information about the authors:}

Privorotskaya T.B. - Senior Lecturer, Department of Chinese Language, Faculty of Foreign Languages, Tomsk State University (Tomsk, Russia).E-mail: kutikova_t@mail.ru

Kosmacheva A.S. - Student, Department of Chinese Language, Faculty of Foreign Languages, Tomsk State University (Tomsk, Russia). E-mail: kutikova_t@mail.ru 